\title{
South American Camelids: their values and contributions to people
}

\author{
Bibiana Vilá ${ }^{1,2}$ [ Yanina Arzamendia ${ }^{2,3}$ (D)
}

Received: 24 May 2020 / Accepted: 8 October 2020 / Published online: 26 October 2020

(c) Springer Japan KK, part of Springer Nature 2020

\begin{abstract}
South American Camelids (SACs) make several material and non-material contributions to people and are a key component of the Andean biocultural heritage. From the perspective of the IPBES' Conceptual Framework, SACs constitute the "nature" component in the complex system of interactions between human societies and the Andean mountain environment. There are four SAC living species today, two of which are wild, or Salqa, in the indigenous cosmovision: guanaco (Lama guanicoe) and vicuña (Vicugna vicugna). Llama (Lama glama) and alpaca (Vicugna pacos) were domesticated 5000 years ago, and are therefore Uywa, in the indigenous cosmovision. Both wild and domestic camelids were, and in several cases still are, the most highly appreciated resource for Andean livelihoods. Historically, camelids and their contributions have been used by Andean people since the peopling of the Americas over 11,000 years ago. In this paper, we present three case studies (chakus for vicuña management, llama caravans, and llama nanobodies) to bring attention to the essential role of vicuñas and llamas for Andean communities today, their intercultural linkages with the Western world, and telecoupling interactions.
\end{abstract}

Keywords NCP $\cdot$ Nature contribution to people $\cdot$ Vicugna vicugna $\cdot$ Lama glama $\cdot$ Andean altiplano $\cdot$ Values

\section{Introduction}

The Intergovernmental Platform on Biodiversity and Ecosystem Services' (IPBES) conceptual framework (Díaz et al. 2015) is a model to analyze socioecological interrelationships. The multiple flows within components in this framework can reveal sustainable or negative trends for nature conservation. In the context of this framework, "nature" refers to the natural world, with an emphasis on biodiversity.

Handled by Shizuka Hashimoto, University of Tokyo, Japan.

Bibiana Vilá

bibianavila@gmail.com

Yanina Arzamendia

yanina.arzamendia@gmail.com

1 National Research Council (CONICET) Argentina, Department of Social Sciences, National University of Lujan, Ruta 5 y 7 (6700) Lujan, Buenos Aires, Argentina

2 VICAM: Vicuñas, Camelids and Environment, Luján, Buenos Aires, Argentina

3 Faculty of Agricultural Sciences, INECOA CONICET UNJU (Institute of Andean Ecoregions, National Research Council -National University of Jujuy), Alberdi 47, (4600) San Salvador de Jujuy, Jujuy, Argentina
Within the context of Western science, it includes categories such as biodiversity, ecosystems, ecosystem functioning, evolution, the biosphere, humankind's shared evolutionary heritage, and biocultural diversity. Within the context of other knowledge systems, it includes categories such as Mother Earth and systems of life (IPBES 2019).

South American Camelids (SACs) are natural beings, members of the tribe Lamini of the Camelidae family. As the other Camelidae tribe, Camelini, including the large humped dromedary (Camelus dromedarius) and Bactrian camel (Camelus bactrianus), SACs are adapted to the extreme conditions of the dry, high-altitude Andean steppes, which has allowed people to settle and thrive in arid lands (Franklin 2011). The four extant SAC species have two very different origins: those that derive from nature without the participation of humans, evolved by natural selection in the wild, and another group that is a co-creation or coproduct of nature and the people who inhabited the Andes 5000 years ago. The wild species, guanacos (Lama guanicoe) and vicuñas (Vicugna vicugna) are Salqa ('natural', 'untamed') in the indigenous and local knowledge (ILK) taxonomic system and they are protected by the Malkus or mountain deities. The domestic species llama (Lama glama) and alpaca (Vicugna pacos) are Uywa, or "the ones that 


\section{Guanaco \\ Wild-Salka}

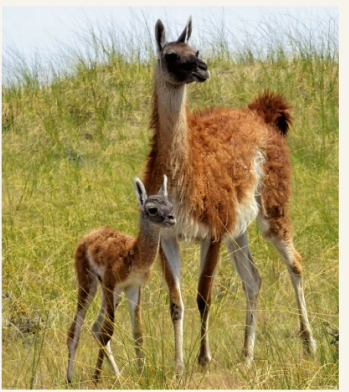

(Lama guanicoe)

Two subespecies:

Lama guanicoe cacsilensis (north) Lama guanicoe guanicoe (south)

Weight 100-120 kgs.

Height at the withers $120 \mathrm{cms}$.
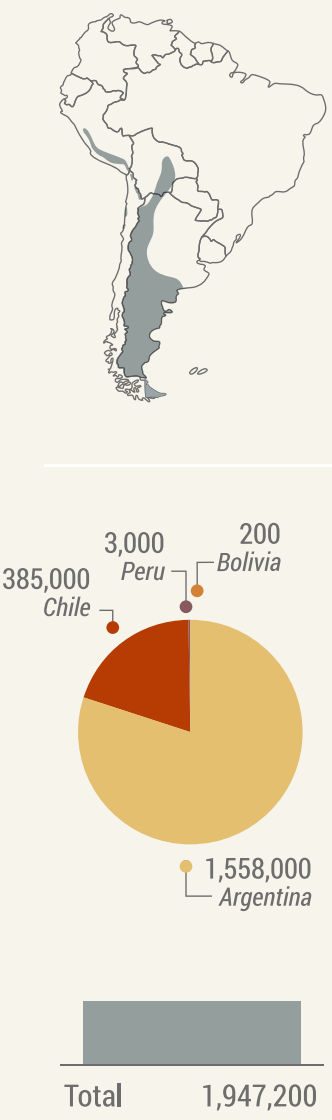

Vicuña

Wild-Salka

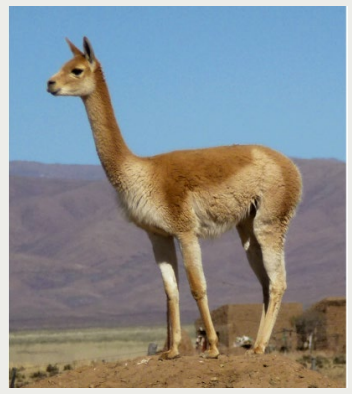

(Vicugna vicugna)

Two subespecies:

Vicugna vicugna mensalis (north) Vicugna vicugna vicugna (south)

Weight $45 \mathrm{kgs}$.

Height at the withers $90 \mathrm{cms}$.
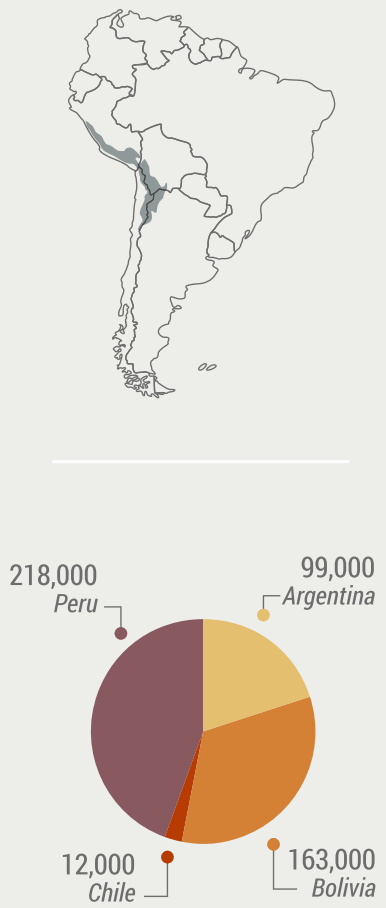

Total

492,000

\section{Llama}

Domestic-Uywa

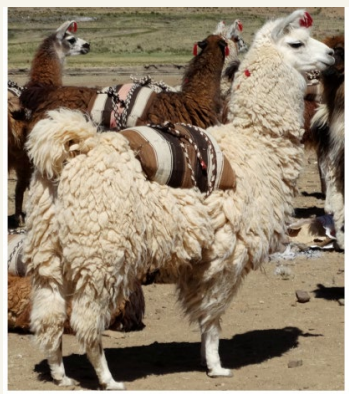

(Lama glama)

Two breeds:

Q'ara (tall and strong, short wooled) Tampulli (hairly, long wolled)

Weight 130 kgs.

Height at the withers $110 \mathrm{cms}$.
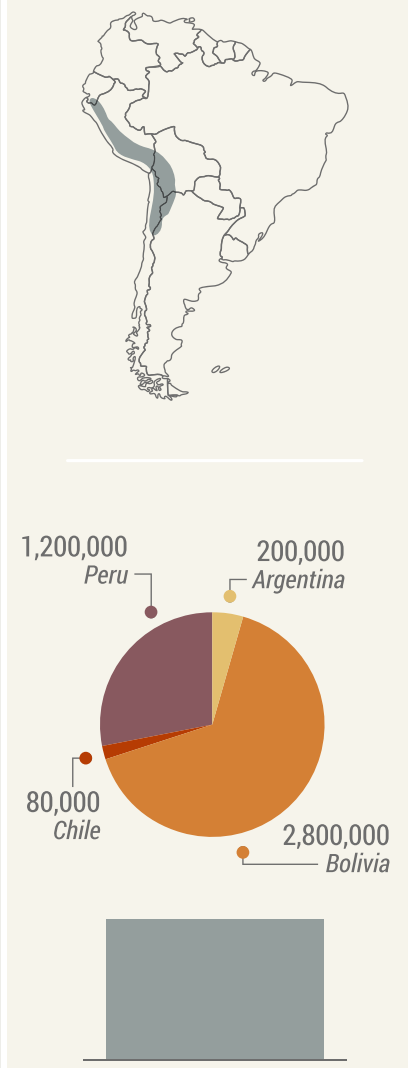

Total

$4,280,000$
Alpaca

Domestic-Uywa

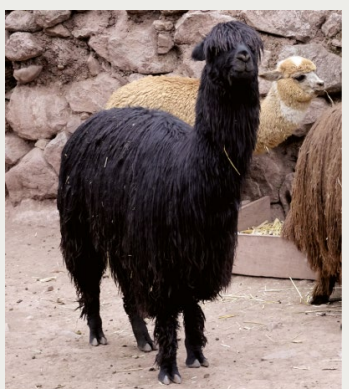

(Vicugna pacos)

Two breeds:

Suri (long straight fiber) Huacaya (wavy fiber)

Weight 60 kgs.

Height at the withers $90 \mathrm{cms}$.
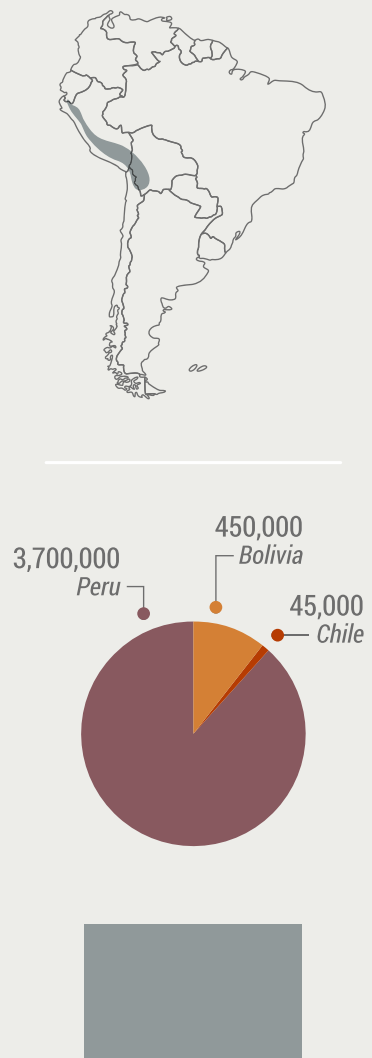

Total $\quad 4,195,000$ 
४Fig. 1 Brief description of the 4 species of camelids. Vicuñas were introduced in Ecuador in 1989, 1993, and 1999 and actually, the population is approximately 7000 individuals. Ecuador also reintroduced alpacas (current population 6700) and llamas (current population 10,000). Chile and Ecuador, FAO 2005. Gonzalez \& Acebes 2016. Acebes et al. 2018. Census of Agriculture, Perú (2012). Ministry of Production Bolivia (2005). National Agronomic Census Argentina (2008). Vilá 2012

belong to people" (Flores Ochoa 1977). The original distribution of the four species includes the Andean high-altitude grasslands, the Altiplano, and the Patagonian arid steppes (Fig. 1). Both wild and domestic camelids have been and, in several cases, still are, the most important resource for Andean indigenous and local communities (IPLCs).

Historically, wild camelids have been used by Andean human groups since the earliest peopling of the Americas, for over 11,000 years (Yacobaccio 2009). Archeological evidence shows that vicuñas and guanacos' contributions to people were essential to the dispersal in the Andes of early American hunters, who benefited from their meat, skin, fur, and even their bones for making tools (Yacobaccio 2001). The exploitation of vicuñas has been regulated since the expansion of the Inca Empire, as a part of the Imperial economic governance system (Cieza de León 1553). PreHispanic capture (Chak'u) of vicuñas involved a large group of people walking slowly and holding ropes with colored strings to drive thousands of vicuñas into large stone corrals for shearing their ultra-fine fiber and culling some individuals (Custred 1979). Since the Spanish conquest, the vicuña population has suffered dramatic losses due to indiscriminate hunting, dropping from 2 million specimens to under 10,000 in 1964 (Wheeler and Hoces 1997). The high price of vicuña fleece in the international market of luxury goods led to the killing and overexploitation of this species, which pushed vicuñas to the brink of extinction (Yacobaccio 2009). After 30 years of proactive, effective protection and management, vicuña populations have recovered sufficiently to make sustainable management projects viable (Lichtenstein and Vilá 2003) for the "benefit of the Andean people" (Convenio Internacional para la Conservación y Manejo de la Vicuña 1979). With a world population of approximately half a million vicuñas, management plans conceived within the paradigm of conservation through sustainable use have been developed in the last decade. Today, live shearing of vicuñas is the only legal way to harvest vicuña fleece, and it is widespread throughout the Andes, albeit with great variability in techniques and therefore, varying degrees of success in terms of sustainability goals (Acebes et al. 2018).

Like vicuñas in the north, the essential role of guanaco in prehistoric Patagonian life is clearly expressed in rock art and zooarchaeological assemblages. Guanacos were exploited intensively for meat, fat, blood, tendons, bones, and skins for clothing and to build shelters. They were the main source of resources for the pre-Hispanic indigenous communities, and they also complemented the resource base of many other farming and pastoralist groups (Miotti 2012). The instrumental, intrinsic, and relational values of this species in the Selk'nam culture were expressed in their worldview in multiple ways, as well as by their language-mostly extinct today - that had more than eleven terms to describe guanaco diversity. The Selk'nam identified sacred areas in which hunting guanaco was taboo, to allow the species to breed freely, and they also maintained several religious and spiritual connections with the animals (Gusinde 1931). After the colonization of Patagonia by European sheep farmers at the end of the nineteenth century, both the indigenous groups and guanacos were killed to clear land for sheep pastures; by 1910 Patagonian rangelands supported about 12 million sheep (Aagesen 2000). These direct actions targeting guanacos due to their perceived role as competitors for sheep has resulted in a dramatic drop in the guanaco population, from over 10 million specimens to approximately 1.5 million in Patagonia, a trend that continues today (Franklin 2011). In the Valdes Peninsula, guanacos have concentrated in the few low stock or sheep-free areas, in a pattern that has been described as "choosing from what is left" (Antún and Baldi 2020). Successful capture and shearing projects have emerged as a conservation strategy through sustainable use of guanacos (Carmanchahi et al. 2015; Lichtenstein and Carmanchahi 2012). These projects have a high value for conservation and sustainable development goals, but supporters of guanaco killings have argued that they are expensive in terms of infrastructure and personnel requirements.

Vicuñas and guanacos were the ancestors of domestic camelids and, in some Andean settings, the wild ancestor and the domesticated form live in sympatry (Franklin 2011). More than 5000 years ago, northern guanacos (Lama guanicoe cacsilensis) were domesticated by indigenous communities, transforming them into llamas. This co-production changed life in the Andes, as it prompted the transition from hunting to herding and the emergence of village-like settlements (Yacobaccio and Vilá 2016). Llamas were an essential part of the biocultural heritage of the Inca culture (Flores Ochoa 1977; Grebe 1984; Vilá 2012, 2014) but the use of llamas as a resource also suffered a large impact after the Spanish conquest and the introduction of exotic cattle, such as sheep, goats, and cows. The social value of this species also changed during historical times, from a highly respected and valued resource in both material and symbolic terms during pre-Hispanic times to being contemptuously regarded as "animals from the Andean Indians" in the Colonial period and early Republican years. More recently, a shift in the cultural environment has led to a renewed appreciation of llamas, associated with the empowerment of indigenous and local knowledge, the recognition of indigenous rights to land, and the acknowledgement of the key ecological role 
of SACs as low impact grazers in arid steppes by conservation ecologists. Thus, llamas have recovered in part, their traditional status as iconic animals of Andean biocultural landscapes.

In addition to llamas, another species was co-produced in the northern Andes: alpacas, whose domestication originated from wild vicuñas (Marin et al. 2017) including substantial hybridization with guanaco/llama (Kadwell et al. 2001). Alpacas were the most important animal for pre-Hispanic groups occupying high-altitude wetlands, providing high-quality fiber and meat (Murra 1965). In the indigenous Quechua language, Allpaka is related to allpa, which means "land", and kamay, which means "to animate". Thus, allpakamasqa can be loosely translated to "animals of the living land". Alpacas are restricted to the Northern, more humid altiplano, typically the Peruvian high-altitude grasslands.

As was made clear by the Global Assessment of Biodiversity and Ecosystems Services by IPBES (2019), humans and biodiversity are intrinsically related, and the IPBES conceptual framework (IPBS CF) provides a mean to visualize the relationships and flows between natural and anthropic components (Christie et al. 2019). As nature components, camelids provide numerous nature contributions to people (NCP), which can be direct, such as their fiber, or indirect, in relation to their multiple adaptations that have earned them their classification as "low impact grazers" (Baied and Wheeler 1993). SACs have morphological (padded feet, mobile lips) and physiological adaptations, such as increased digestibility due to retention of particles in the pseudo-rumen that allows them to use forage low in protein and high in fiber, in addition to high efficiency in the metabolic use of water (compiled in Gimpel and Bonacic 2006). Thus, thanks to this herbivore-plant co-adaptation, the maintenance of grassland in which they feed can be counted among camelids' NCPs, including water regulation, carbon sequestration, and biomass production (NCP categories 1, 4 and 12) (Díaz et al. 2018; Martin-Lopez et al. 2019).

From a biocultural perspective, SACs have different relational values and roles within diverse worldviews, including the scientific, indigenous, and local knowledge systems, and these roles and values have also undergone change over time. Camelid NCPs can be analyzed in the context of diverse values and perceptions -as resources or commodities, sacred beings, utilitarian, non-human companions, etc. These values and perceptions motivate the decisions made by different stakeholders and the type of interactions they have with these animals, from strict conservation strategies to poaching.

The intensity of a person's valuation and emotional connection with nature is related to several factors including his/her sensitivity, and intellectual experiences (Ives et al. 2019).
Understanding the values and attitudes of indigenous people and local communities (IPLCs) towards wildlife use should be a research priority for in situ sustainability and conservation management (Arias Arevalo et al. 2017; Pratt et al. 2004). But in the globalized world, even camelids are altered by multiple human drivers, some of them involving long-distance interactions (telecouplings). While the concept of buen vivir ("good living") has its origin in Andean IPLCs and is firmly rooted in the relationship between Andean people and SACs, today it is impossible to approach conservation from an isolated "natural" or "social" science perspective. Many institutions and international organizations have emphasized the need for an integrated approach that incorporates an intercultural human dimension into biodiversity- conservation policies and programs (Batisse 1986; CEESP 2003; IPBES 2019). As scientific conservation practitioners, in this paper, we seek to describe our experience working with wild vicuñas chakus and llama caravans, as case studies to illustrate the multiple contributions to people of a wild and a domestic camelids species. We emphasize the diverging significance and meaning of these species and their contributions to different stakeholders: IPLCs, the scientific community, local authorities, llameros (lama caravaneers), local schoolchildren, luxury fiber companies and high fashion brands, and molecular biology labs.

\section{Materials and methods}

We selected three case studies in which members of the VICAM team were professionally involved (the authors were main researchers in two of them) to illustrate human interactions with two species that are the most common camelids in the Altiplano, NW Argentina.

1) Vicuña management practices (chakus).

2) Llama caravans.

3) Llama nanobodies.

The first two are based in Santa Catalina, one of the densest endemic distribution areas of both camelids in the Altiplano of Jujuy Province, Argentina.

Santa Catalina is a small traditional town, located in the mountain range of Rinconada, in the fluvial valley of the Santa Catalina River, at $3800 \mathrm{~m}$ above sea level. It is the northernmost town in the country, bordering with the Plurinational State of Bolivia. Founded in the seventeenth century, the town consists mainly of adobe (dried mud) houses clustered around a historical heritage church. Santa Catalina concentrates the administrative, political, sanitary, commercial, religious, festive, and educational functions in the area, including an elementary and a high school. 
The pre-Hispanic communities that lived in this area had strong interactions with camelids, as proven by the petroglyphs depicting these animals in the northern sector of the village. The current indigenous habitants are united in three communities called Aukarpina Champi, Athu Saphi and La Cruz. There is also a cooperative of livestock producers (COOPASAC), which bring together local landowners. The main economic activity in the area is breeding -sheep and llamas- to produce fiber, skins, and meat. Governmental aid programs also constitute a significant source of income for many households.

\section{Field data}

The ethnobiological data presented in this paper were obtained during a participatory process developed over the past decade, comprising communal meetings, workshops, fairs, and other events, in which the authors have generated intercultural dialogues and exchanged information. Data collection methods included:

1. Ad libitum surveys during the Annual Santa Catalina Fair (llama caravans) and vicuña chakus.

2. Participant observations.

3. Recorded dialogues between participants in these public events.

4. Specific questionnaires, especially regarding camelid valuation and use.

5. Unstructured interviews and open surveys.

Data on chakus were obtained from the vicuña management plan of Santa Catalina, a joint project between the VICAM research group (technical manager) and the COOPASAC (local manager) that began in 2011. The management plan involves diverse stakeholders, including representatives of IPLCs, the local school communities, interdisciplinary researchers and university students. To date, we have held over 20 meetings with local communities and COOPASAC, contributing to build capacities among locals (approximately 200 people) and training over 150 students. Together, we developed four chaku events between 2012 and 2018. The fluent dialogue between our different knowledge systems was key to conduct successful chakus.

Data on llama caravans were obtained annually from 2011 to 2019, at the 2 to 3-days-long fair that precedes the town's Patron Saint anniversary celebration (Saint Catherine of Alexandria, or Santa Catalina) on November 25th. Over the last seven years of research at the fair, 260 open interviews were recorded (37 per year, in average) covering a variety of topics related to llama caravans. The results presented here are based on the information collected in those interviews that specifically matches the elements of the IPBES CF.
All the survey was conducted under the code of ethics for research, research-action, and ethnoscientific collaboration in Latin America (Version two) of SOLAE, the Latin-American Society of Ethnobiology.

Data on llama nanobodies was obtained by a non-systematic literature review and by a dialogue with an expert in molecular biology.

\section{Data analysis}

The data were analyzed using a deductive approach and classified into categories following the IPBES CF, as described in their seminal paper (Díaz et al. 2015). These categories were:

\section{Anthropogenic assets}

Built-up infrastructure, health facilities, knowledge (including ILK systems and technical/scientific knowledge, as well as formal and non-formal education), technology (both physical objects and procedures), and financial assets, among others.

Drivers: natural or anthropogenic (human-induced) factors that cause a change in nature, either directly or indirectly. Direct drivers, also called pressures, operate directly on nature, while indirect drivers operate by altering the level, direction or rate of change of one or more direct drivers. Direct anthropogenic drivers are the result of human decisions, namely, of institutions and governance systems and other indirect anthropogenic drivers, which concern the ways in which societies organize themselves. They are the underlying causes of environmental change that are external to the ecosystem in question, on which they operate through direct drivers. Finally, direct natural drivers are not the result of human activities and are beyond human control.

Nature: the natural world, with emphasis on the diversity of living organisms and the interactions among themselves and with their environment.

Nature's benefits to people: All the benefits (and occasionally losses or detriments) that humanity obtains from nature.

Along with these categories, the information was analyzed by considering the different values that stakeholders assign to these elements and relationships, as defined by Arias Arevalo and colleagues (2017): instrumental value, or usefulness as a means to an end; intrinsic value, or the value of nature, ecosystems, or life as ends in themselves, irrespective of their utility to humans, and relational values: the importance attributed to meaningful relations and responsibilities between humans and between humans and nature. 


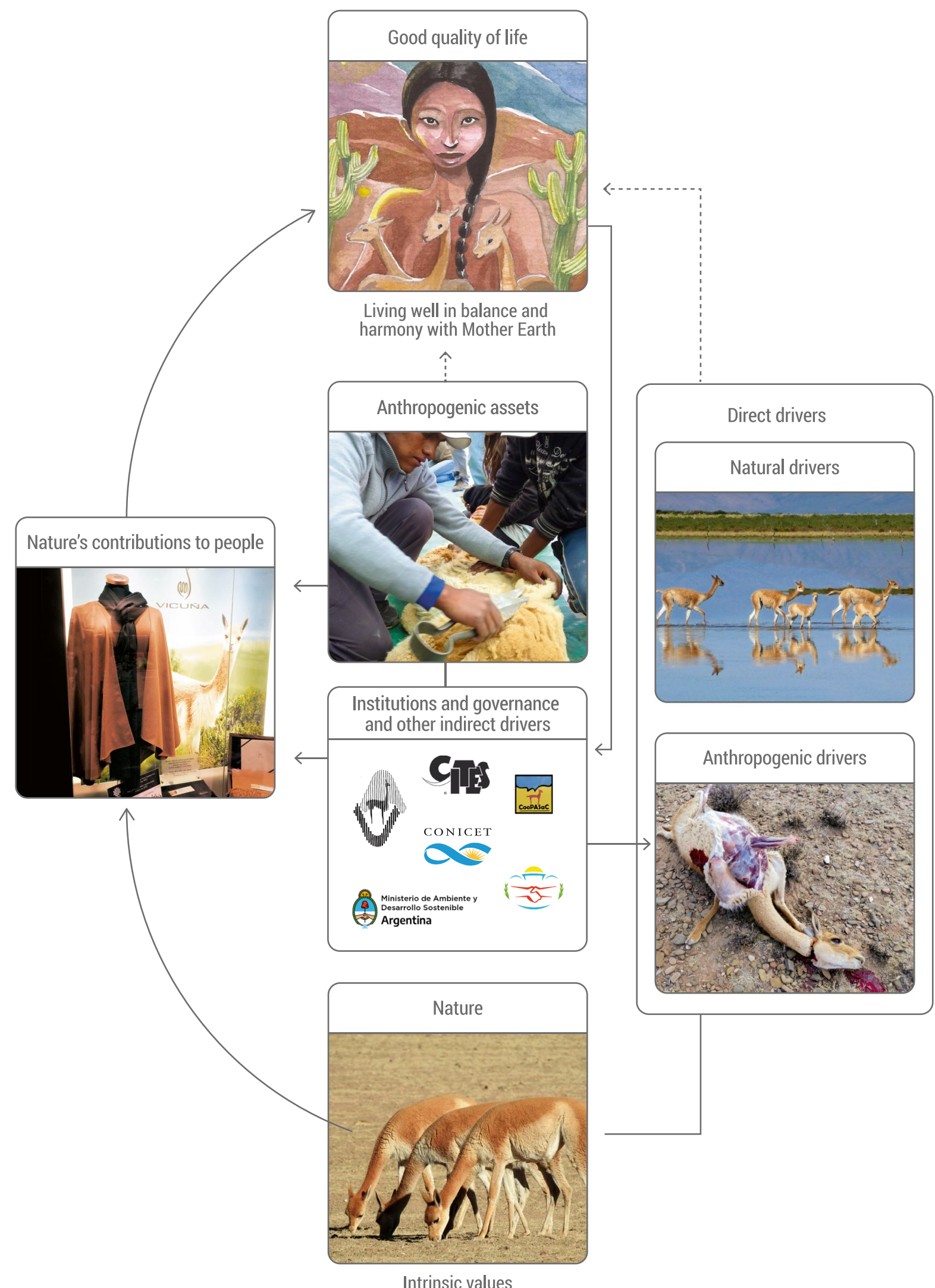


४Fig. 2 Images from vicuñas case study (chaku) visualizing some real images of components. The quality of life is "Pachamama with vicuñas" an original drawing of Carlos Julio Lopez owned by VICAM. The photographs of vicunas in "nature" is Yanina Arzamendia's authorship. Bibiana Vilá is the author of the rest of the photographs

\section{Results}

\section{Chakus: the case of vicuña management}

The nature element analyzed in this case study is the southern vicuña (Vicugna vicugna vicugna). The local perception of this species includes an intrinsic valuation of vicuñas as animals owned by the Pachamama (Mother-Earth) deity, they are her property. "But who do they (vicuñas) belong to? ... I say they belong to nature ... to La Pachamama, you cannot own the vicuña, ... it is not allowed" (AG local community member, male). Coquena is the shepherd-deity that protects vicuñas, he/she (it has an ambiguous gender) appears permanently in oral narrations about the species in this area (Vilá 2014, 2015): “My aunt's nephew [...] said he once found a baby vicuña, he wanted to take her home, she was alone in the field... Suddenly a Coquena appeared to him and said to him:-Leave that vicuña alone, it is mine, what's wrong with you? Release her. And he released her and left, crying and scared. Coquena was like a little boy or a goblin, with a very big hat ... Coquena said: Leave it [the vicuña] because she is my property, she belongs to me. So, from that moment on, every time that my aunt found a little vicuña, she never raised it [in her arms] because she was afraid" (GL local community member, female).

As presented in the introduction, vicuñas have one of the most valuable natural fibers in the world that, if it is well managed, can contribute greatly to the quality of life of Andean IPLCs. The high quality of vicuña fiber has been appreciated since pre-Hispanic times, and local people who had woven it before its exploitation was banned said that vicuña wool is "very thin, soft, tiny, fluffy, is (...) How beautiful it is to spin ... soft, if it is done with a thread lathe ... the wool is soft" (PM local community member, female).

In Fig. 2 we consider vicuñas and their values to people in the context of the IPBES CF. The nature element in question is the vicuña itself, a wild, low impact grazer with one of the finest fibers in the world, which is used as raw material for luxury garments (NCP). To obtain this fiber in a sustainable way it is necessary to employ a specific technique of capture, shearing, and release called chaku (anthropogenic asset). Several institutions and legal frameworks are involved in this process, and their policies shape the activity, including international agreements (CITES, Vicuñas convention), governmental agencies from the national (Ministry of Environment, the National Research Council), and provincial levels (Ministry of Environment of Jujuy), and local organizations
(COOPASAC). Direct natural drivers can include very strong storms that cause flooding. The anthropogenic driver that is the most serious threat to the conservation and longterm survival of the species is poaching. Quality of life involves, among other elements, the strong cultural link between vicuñas and the local belief in Pachamama as the mother of life and of vicuñas. These components and values are described in Table 1.

Stakeholders, operating through CF components and their flows, can either facilitate or hinder the sustainability of the system and thus enhance or compromise its ability to contribute to the wellbeing of local communities. Some of the main actors involved in the drivers described in the $\mathrm{CF}$ for the vicuña case study can be found in Table 2.

\section{Llamas}

Llamas are the result of a co-production between wild northern guanacos and human societies. They are domestic multipurpose animals that provide fiber, meat, bones and dung, and they have a deep bond with Andean culture. The Central Andes is a complex mosaic of landscapes and humans, whose livelihoods require material ecosystem resources from different altitudes. In the past, this necessity was met by implementing a vertical complementarity strategy, using llama caravans for transport (Clarkson and Briones 2001; Nielsen 2002). Caravans arrive annually to Santa Catalina to participate in an event that can be traced back to the nineteenth century: the town's patron saint's anniversary celebration on November 25th, which was preceded by a fair. The fair is a traditional market where pastoralist products such as fiber, dried meat (charqui and chalona), fat, and vegetables are sold and bartered for industrial food products (flour, sugar, pasta). The fair also includes used and new clothes and toys, traditional medicine, small appliances, furniture, and typical food and drink stalls. Llama caravans arrived from Bolivia (nor Lipez area) after a 6-day journey across the mountains, bringing llama fiber to exchange for industrial foods that come to the fair by truck from large cities in NW Argentina. People who lead and travel in the caravans (llameros) belong to indigenous communities and are bilingual Quechua-Spanish speakers. The main exchange is llama fiber for 50-kg sacks of flour; the exchange rate can vary considerably, from $44 \mathrm{~kg}$ of fiber to one sack of flour in 2013, to nine to one in 2018. Truckers claim that the rates are based on international commodity prices. For the llameros, the fair is their greatest opportunity to obtain a yearly supply of processed or industrial foods; since they do not use money, bartering is the only way to acquire them. Intra-ethnic exchanges usually involve smaller quantities and a greater diversity of products; the value of the barter is agreed between the two parties and it is not subject to the fixed prices of the external market. Caravans are currently 


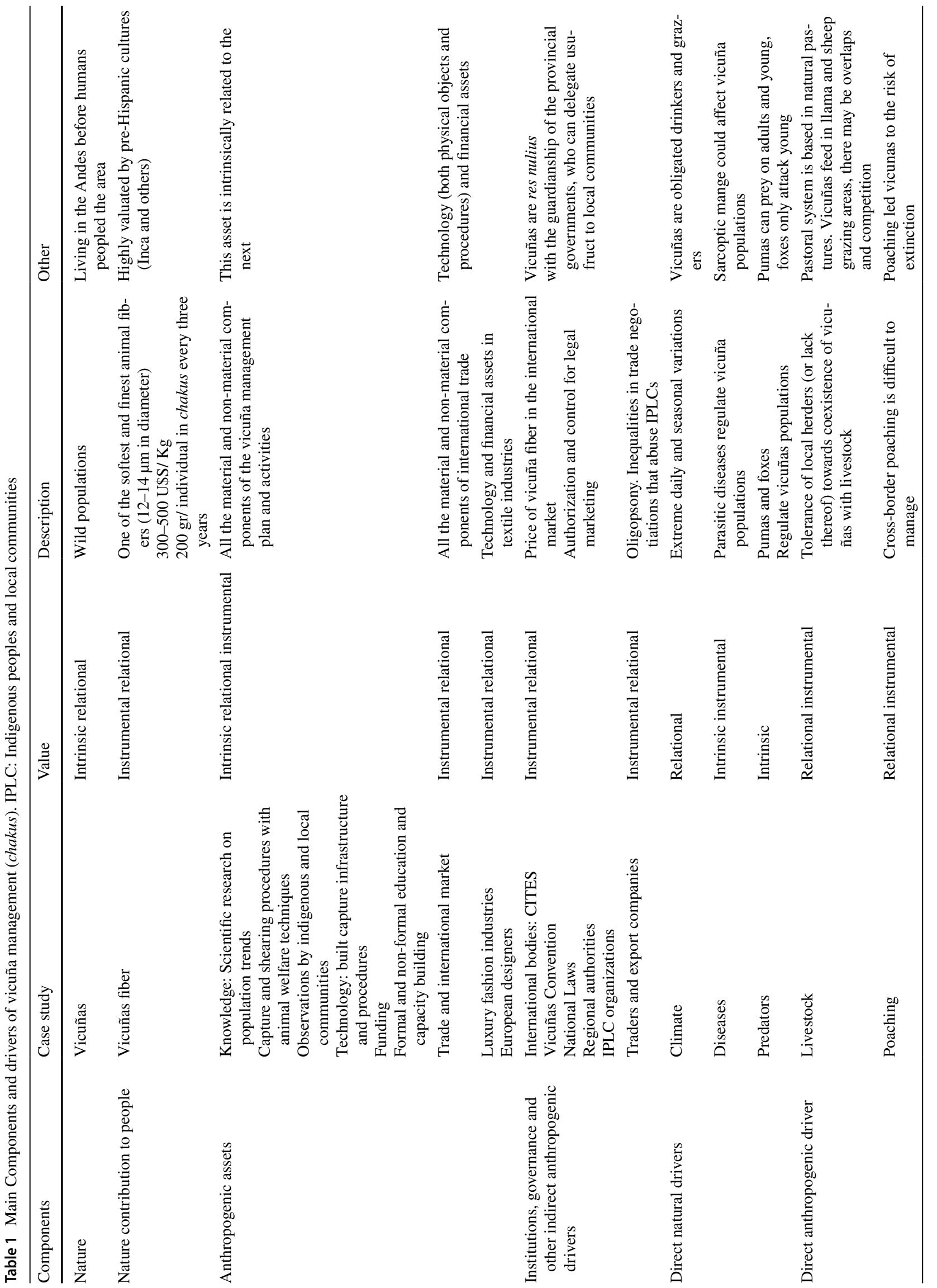


scarce and are in danger of extinction if they have not gone extinct already (Vilá 2018). As noted by locals “... they [llameros] used to come in greater numbers ... they would cover all this mountain with llamas ... the wool is not worth much, because of this they do not come [...] There are no more llamas because people have already changed, vehicles arrive, when vehicles did not arrive before, now one can pay for a truck, it picks them up and they come." (LW, female). The reasons include the climate and socioeconomic drivers since improved economic conditions in Bolivia have enabled llama producers to engage motor vehicles for the journey. An ex llamero pointed out that "before there was no mobility [meaning 'motor vehicle'] and we all had to walk with llamas (...), once you have mobility, you cannot walk, it gets tiring after a while, that's the problem, people are weaker, now everyone has mobility thanks to Evo [Morales, the President of Bolivia]" (HU participant in the fair that came from Bolivia). Another factor that is bringing about the end of caravans is the little enthusiasm shown by young members of the local communities to continue with the activity (Vilá 2018). Some of the components and drivers of llama caravans described are presented in Fig. 3 and detailed in Table 3 .

The stakeholders of llama caravans, operating by the components and flows, show the vulnerability of this livelihood (Table 4).

\section{Llamas and their special antibodies}

One of the most surprising NCPs from llamas -and all members of the Camelidae family- are their unique antibodies. Recombinant gene technology has made it possible to extract small antibody fragments called nanobodies (Nbs) or $\mathrm{VHH}$ (variable heavy homodimers) from camelid heavy chain antibodies. Camelid VHHs have exceptional physicochemical properties, including the possibility of humanization, which makes them uniquely well suited to deliver biologicallyactive compounds (Unciti-Broceta et al 2013). Llamas have become a significant animal in recent human immunology research because they have smaller and simpler nanobodies that fit into more recessed binding sites on the viral surface (Wesolowski et al 2009) and can be used for a variety of therapeutic applications. To cite just one example, VHHs are able to withstand extreme $\mathrm{pH}$ values and are therefore very effective to deliver immunotherapy for diarrhea caused by rotavirus (Maffey et al. 2016). These antibodies are used for experimental and therapeutic research in many laboratories which means that llamas are kept as lab animals in several research institutes around the world.

The quality of life component of the conceptual framework is represented as the potential cure of several diseases through vaccines and therapeutic techniques using llama nanobodies (Table 5). 
Table 2 Main actors and the role of the anthropogenic drivers described in the CF for the vicuña case study

\begin{tabular}{ll}
\hline Component & Stakeholder \\
\hline $\begin{array}{c}\text { Institutions and other indi- } \\
\text { rect drivers of change }\end{array}$ & International CITES
\end{tabular}

International vicuña convention

National and regional environmental government

Associative local Andean boards (Communities and cooperatives)

Traders and export companies

Extra-Andean (mostly in Italy, rest of Europe, Japan and USA) luxury fashion industries

European designers

Weaving craftswomen

Research, academic, technical institutions and Universities

Anthropogenic direct drivers Poachers (can be members of communities from neighboring countries)

Trained researchers, technicians and local community members

Improvised and untrained people

Conservationists

Local peasants (some)

Local peasants (some)
Role/description

To ensure that international trade in specimens of wild animals and plants does not threaten their survival. To establish specific trade conditions for different species. Authorizes export and import through a licensing system

Article 1: The signatory governments agree that the conservation of vicuñas constitutes an alternative of economic production for the benefit of the Andean population and commit to its gradual use under strict governmental control, applying the techniques for the management of wild fauna determined by their competent official bodies

To set guidelines for sustainable management, law enforcement, and surveillance (inspections for the authorization of the legal sale of fiber; wildlife crimes) and to apprehend and prosecute poachers through security forces and the judicial system

To receive usufructuary rights for the capture, shear, and trade of vicuña fiber through public tenders, or direct sale. Some have the technical ability to weave handmade garments. They are IPLCs with very little income, most of them making just enough to cover their basic needs. They have inequity in negotiations with traders

Financial capital for the purchase of fiber

To trade vicuña garments in the international market. Buyers belong to an affluent social class that is able to pay thousands of euros for a garment

Telecoupling

A market for typical handmade ponchos exists among the rural squirearchy

To provide data for guidelines on the management of the species. Design of management plans and technology, intercultural dialogue with IPLCs

Poaching is still the main risk for vicuña populations

Sustainable use: Chakus can be performed with techniques that allow zero animal mortality. It reinforces traditional resource use and community organization

Unsustainable use: The lack of proper capture techniques and procedures can put vicuña populations at risk

Actions to increase vicuñas populations

Disturbance: due to perceived competition for pastures, vicuñas are chased away from llama and sheep grazing areas

Tolerance: Vicuñas are valued in relation to deities, Coquena (their shepherd), and the Pachamama who protects them. Their presence is accepted based on possible or real use 
Table 2 (continued)

\begin{tabular}{|c|c|c|}
\hline Component & Stakeholder & Role/description \\
\hline \multirow[t]{6}{*}{ Anthropogenic assets } & Local communities or cooperatives & $\begin{array}{l}\text { IPLCs individuals trained and advised to carry out } \\
\text { vicuña management. Drivers of wild vicuñas into a } \\
\text { corral }\end{array}$ \\
\hline & IPLCs builders & Local manufacturers of the capture funnel and corral \\
\hline & IPLCs Shearers & Specialists in shearing with scissors \\
\hline & Researchers & $\begin{array}{l}\text { Research on vicuñas ecology, animal welfare, and man- } \\
\text { agement impact. Technical procedures and technology } \\
\text { of capture and shearing. Research on biological and } \\
\text { social conservation and use of vicuñas. Environmental } \\
\text { education }\end{array}$ \\
\hline & Local schools & $\begin{array}{l}\text { Environmental education, from a mixture of traditional } \\
\text { and Western hegemonic knowledge on the Andean } \\
\text { environment }\end{array}$ \\
\hline & $\begin{array}{l}\text { Luxury garment businessmen, shopkeepers European } \\
\text { designers and industries }\end{array}$ & $\begin{array}{l}\text { They employ numerous people in industry and com- } \\
\text { merce }\end{array}$ \\
\hline
\end{tabular}

\section{Discussion}

The conceptual framework was applied to landscapes (mountains), natural resources (fisheries), and several ecosystems (Díaz et al. 2015; IPBES 2019; Martin-Lopez et al. 2019), including the socio-cultural valuation and knowledge of IPLCs (Christie et al. 2019). This is the first work to apply the framework to vicuñas and llamas, providing a useful tool to analyze interrelationships between natural aspects, local knowledge, institutional and socioeconomic issues. One added value of this approach is the clarity with which the CF shows the problems in camelid management arising from the "wild vs. domestic essence" categorization of SACs. By applying the CF, the relationships that increase or hinder the sustainability of the system could be readily observed. Separated CF of llamas and vicuñas has allowed us to compare the situations of two related species in the same ecosystem, as well as the different challenges and research questions that need to be answered to devise appropriate solutions. For example, the main "natural driver" in the altiplano is the harsh climate, which is the same for both species. However, vicuñas are directly exposed to its effects, whereas people act as buffers between these natural drivers and llamas-e.g. the lightning strike killed the shepherd, not the llamaprotecting the animals from natural agents when possible. Similarly, while anthropogenic drivers that affect vicuñas include poaching, that costs the animal its life, among llamas, this is not an issue. Instead, it is the use of vehicles to replace llama caravans to transport the fiber one of the main drivers of change among llamas and their interrelations with people and the habitat. Thus, this novel application of the $\mathrm{CF}$ to think about traditional environmental issues, such as the roles of camelids in the altiplano, has helped to advance the understanding of the complexity involved in these roles and in the implied interactions with diverse stakeholders.

We also found this CF useful to organize and reflect upon the results of interdisciplinary research from a problem-oriented perspective (Kueffer et al 2012). By describing the systems, the role, disparate power and interests of stakeholders, their geographical location, the diverse institutions and processes, the fiber and the thousand dollars garment, the resulting $\mathrm{CF}$ is solidly based in reality, rather than in theoretical constructs or expectations. Among other benefits, this has helped us to demystify pernicious messages, such as the idea that "vicuña is the gold of the Andes" that could provide a quick and uncomplicated way to generate income for IPLCs.

This CF has also incorporated the voice of partners outside the academia. For example, llama caravans are undergoing a process of change, whose outcome will depend primarily on the attitudes of llameros and young members of the local communities. These attitudes are among the CF's anthropogenic drivers and assets, both influenced by institutions that can be located very far away, such as the International Wool Textile Organization in Belgium, or very nearby, such as the local school. Our framework brought to light both the factors that can predict the extinction of llama caravans while simultaneously explaining the maintenance of llama fiber trade transported by vehicles.

In terms of opportunities to research camelid conservation problems cannot always be equated to their endangerment as a species; in some cases, it is quite the opposite, with specific conservation challenges arising from the species' abundance. Abundant species attract far less attention from biodiversity conservation institutions, which hinders the maintenance of in situ research and sustainable 


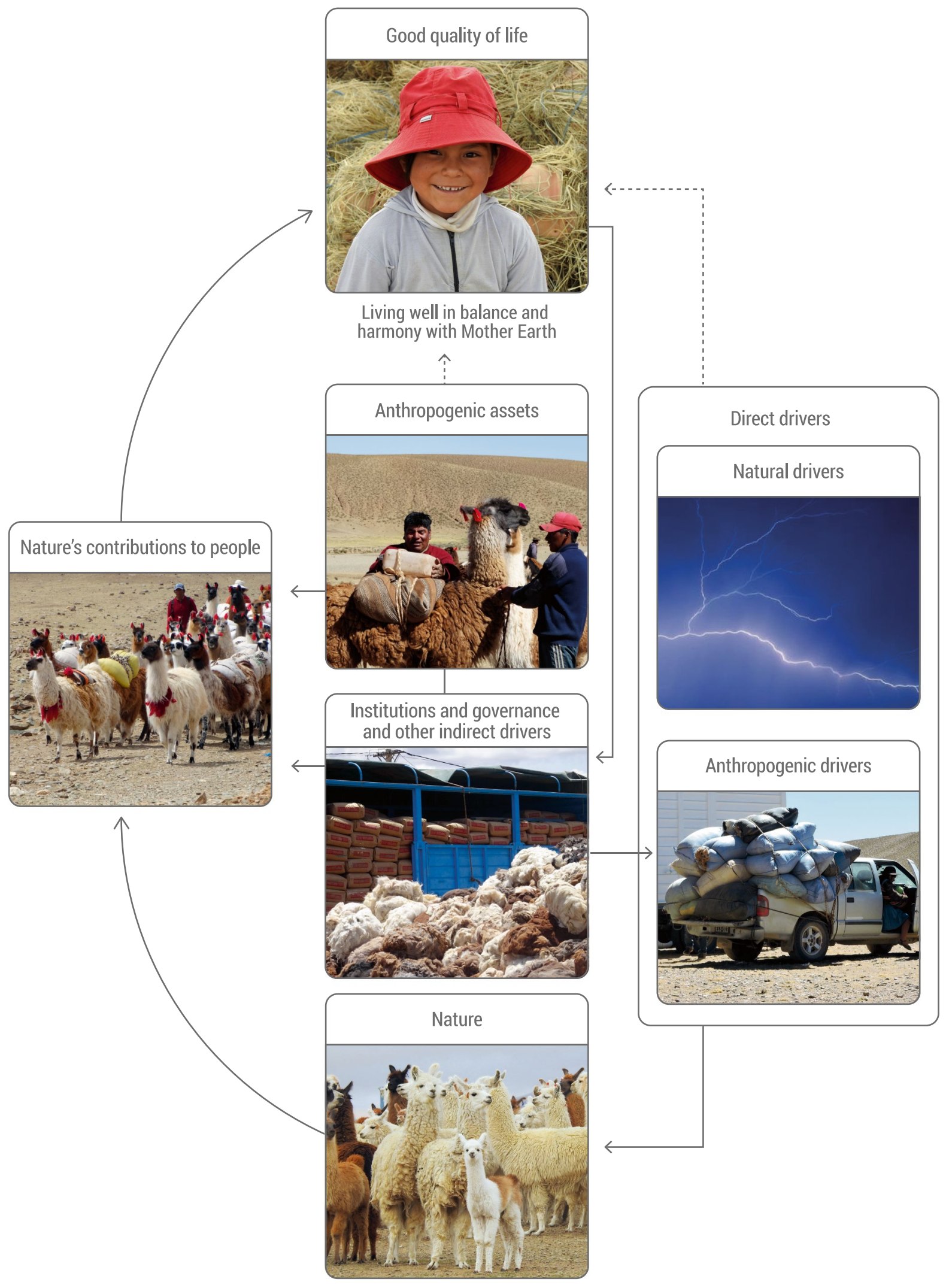

Intrinsic values 
4Fig. 3 Images from the llama's case study visualizing different images of the $\mathrm{CF}$ components. All the photographs were taken by Bibiana Vilá except the lighting (natural drivers) obtained from the internet. The imagen of Madeleine (Good quality of life) has the girl and her mother's permission

management projects. But abundance has enough merits to be considered as a significant phenomenon for conservation in itself. As has been eloquently expressed by Redford and colleagues (2013), "Wildlife in abundance, sometimes referred to as wildlife spectacles, helps inspire us and builds connections with the natural world... Abundance is a buffer from perturbation whereas rarity is perpetual vulnerability". In other words, the abundance of a wild species has a relational value, and it can contribute to protecting other species. In this sense, protecting wildlife abundance can be considered to have an intrinsic value as part of a comprehensive strategy for sustainable use, particularly in species that are amenable to human management.

\section{Vicuñas chaku}

Vicuñas have intrinsic value due to their particular adaptations as low impact grazers in harsh, desert environments; they also have instrumental value as fiber producers, and several materials and relational values due to their close relationship with Andean cultures. For distant western stakeholders of international textile industries, vicuñas are a way to achieve huge profit margins. The role of local Latin American environmental authorities is crucial to bridge the extremely wide cultural gap between producers and buyers (Lichtenstein 2010). Textile companies usually lobby local environmental authorities in Latin America. Unfortunately, this results in a biased mediation which is almost always in favor of the greatest economic power. Vicuñas management under strict animal welfare protocols has shown biological sustainability in Argentina (Arzamendia and Vilá 2012; Arzamendia et al. 2010, 2014; Vilá et al. 2010) but anthropogenic drivers (direct and indirect) interact in such a way that the long-awaited sustainable development goals are yet to be achieved.

Vicuña management via chaku-like practices has the potential to significantly increase the income of Andean communities (Lichteinstein and Vilá 2003), but a detailed market analysis (Kasterine and Lichtenstein 2018) has revealed that only $2-6 \%$ percent of the garment retail price actually reaches Altiplano communities. Due to culturaland even language-barriers, IPLCs are poorly suited to stand their ground against international textile companies, who have more resources and lobby capacity to tilt the scales in their favor when negotiating trade conditions. In this sense, national institutions and governance systems-the indirect anthropogenic drivers as per the IPBES
Conceptual framework-have a critical role to play to reduce asymmetries and guarantee fair trade. The situation is not new; Sahley and colleagues (2004) pointed out that, because vicuñas can be live-shorn by indigenous communities, it is the "ultimate" eco-friendly, wild animal product for the high-end fashion industry, which opens up a precious marketing opportunity. But they also noted that peruvian bureaucracy and legislation create serious difficulties for peasant communities to participate in the chain of production and commercialize their fiber. Lichtenstein (2010) also described complex relationships between local communities and the global market and underscored the importance of government policy in helping communities overcome these inequalities.

In Argentina, IPLCs cooperatives and communities have received technical and material governmental assistance for the chaku activities, either from provincial governments or the national science agency (National Research Council, CONICET) and academic and technical organizations, in the form of free professional technical support for environmental assessments and drafting of vicuña management plans, supplies (e.g. nets on loan) and staff, such as volunteer university students and security forces, to assist in vicuña captures. This support has allowed IPLCs to afford production costs in a monopsony situation, where a single buyer controls the market of vicuña fiber. However, prices have decreased to less than 400 dollars per kilogram (Kasterine and Lichtenstein 2018) and external support for the sale of the fiber is considerably less developed, which involves cumbersome procedures for IPLCs. Of the 18 NCP reporting categories (Díaz et al. 2018), the price of vicuña fiber only reflects category 13 , its instrumental value, which is fixed by international markets. As can be appreciated in this work, vicuñas also account for other NCP categories, such as learning and inspiration (category 15), physical and psychological experiences (16), maintenance of options (18) and especially category 17 , or "supporting identities", since the chaku is both a technique and a ceremonial event, deeply rooted in Andean cosmovision and tradition.

\section{Llamas}

The two llama case studies were selected to illustrate the wide spectrum of this species' contributions to people. On one hand, llamas are loaded with woven llama fiber sacks that are tied to the animal using llama fiber ropes, to carry llama fiber across the Andean mountains on a 6 day journey to a local market. On the other, high-tech molecular engineering of llama nanobodies is used for biomedical research purposes in the most prestigious laboratories and institutions in the world. Llamas are incredibly versatile animals that connect the past and the future and foster telecouplings between such diverse actors as subsistence fiber producers in 


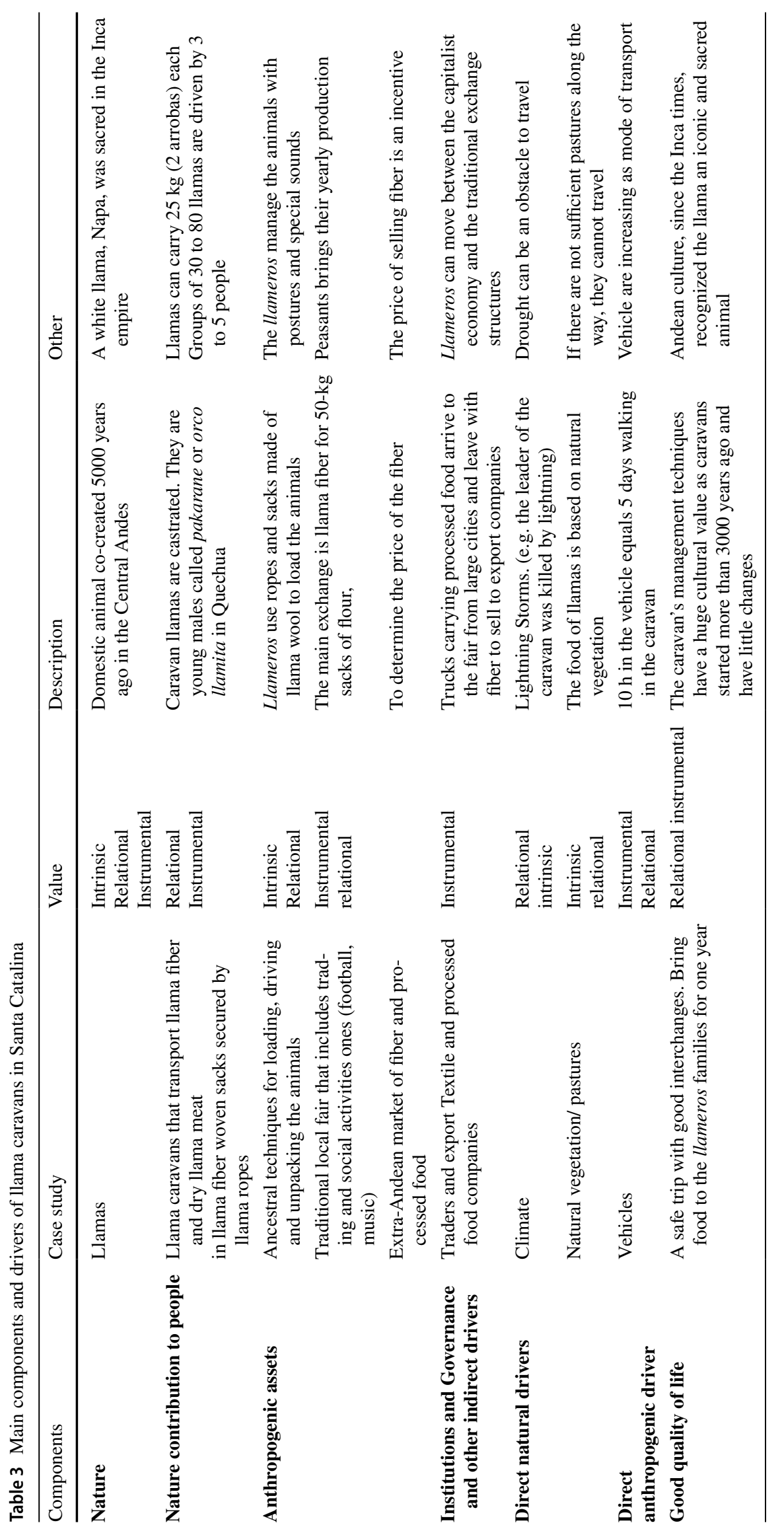


Table 4 Main actors and role of the anthropogenic drivers described in the CF for the llama caravans case study

\begin{tabular}{|c|c|c|}
\hline Component & Stakeholder & Role/description \\
\hline \multirow[t]{5}{*}{$\begin{array}{l}\text { Institutions and other indi- } \\
\text { rect drivers of change }\end{array}$} & $\begin{array}{l}\text { Nor Lipez herders' communities } \\
\text { llameros }\end{array}$ & $\begin{array}{l}\text { The caravans depart from the llameros' homes in } \\
\text { Bolivia. A propiciatory ritual is carried out at } \\
\text { departure, which consists of smoking the animals } \\
\text { by burning coa, a local plant. Then, they guide the } \\
\text { caravans on a six-day journey across the mountains } \\
\text { to Santa Catalina }\end{array}$ \\
\hline & Santa Catalina local authorities & $\begin{array}{l}\text { Administrative, Religious and recreative activities in } \\
\text { town }\end{array}$ \\
\hline & $\begin{array}{l}\text { Santa Catalina Fair organizers. Local people associ- } \\
\text { ated with the authorities }\end{array}$ & $\begin{array}{l}\text { Place of exchange } \\
\text { Social activities, music, food, football }\end{array}$ \\
\hline & Border authorities & $\begin{array}{l}\text { Allow the passage of animals, people and goods from } \\
\text { Bolivia to Argentina and back }\end{array}$ \\
\hline & $\begin{array}{l}\text { Traders and Truckers with information on } \\
\text { Fibre market export companies and processed food } \\
\text { wholesaler }\end{array}$ & $\begin{array}{l}\text { Determine fibre to flour exchange rate, which is the } \\
\text { main exchange of the fair }\end{array}$ \\
\hline \multirow[t]{2}{*}{ Anthropogenic direct drivers } & Llameros transition to transport by motor vehicles & Extinction of caravans and caravan technologies \\
\hline & $\begin{array}{l}\text { Non-IPLC individuals breeding pack llamas and train- } \\
\text { ing them to walk }\end{array}$ & Using llamas' caravans as touristic attraction \\
\hline \multirow[t]{5}{*}{ Anthropogenic assets } & Llameros & $\begin{array}{l}\text { Quechua-speaking IPLCs with knowledge and experi- } \\
\text { ence in breeding, training, and travelling with cargo } \\
\text { llamas }\end{array}$ \\
\hline & Researchers & $\begin{array}{l}\text { Observing all the stages of the caravan trip to have a } \\
\text { record of the activity after its extinction }\end{array}$ \\
\hline & Local schools & $\begin{array}{l}\text { Using caravans as a transversal theme for different } \\
\text { subjects, such as mathematics, geography, history, } \\
\text { and natural sciences }\end{array}$ \\
\hline & Local people & $\begin{array}{l}\text { Visitors, musicians, greengrocers, cooks, shopkeepers, } \\
\text { traditional medicine women, among others }\end{array}$ \\
\hline & $\begin{array}{l}\text { Traders and truckers, textile companies, and processed } \\
\text { food wholesaler }\end{array}$ & $\begin{array}{l}\text { Financial capital for the purchase of food or fiber } \\
\text { Infrastructure and technology with use of labor }\end{array}$ \\
\hline
\end{tabular}

an Andean town and golf players in the UK that use llamas as caddies.

In the Andes, a direct natural driver (lightning) killed the last caravan leader in 2019. No caravans have arrived in Santa Catalina since then, and we can conclude they are now extinct. Fewer people are choosing to remain in the rural Andean Altiplano, which is a local expression of a global pattern of abandonment of traditional livelihoods. Global pastoralist populations have decreased from 10 to $1.5 \%$ of the total global population over the last five decades (Faye 2016). Local people attending the Santa Catalina fair in 2018 and 2019 commented on what they considered to be the reasons for the decline in caravan trade at the fair: (a) a growing demand for camelid fiber in Bolivia; (b) the improvement in living conditions, which allowed peasants to use motor vehicles to transport the products; and (c) the drought that affected the area during the 2014-2017 period. In their detailed paper analyzing seven pastoral regions in six continents, Dong et al. (2011) found that three factorsagroecosystem resilience, livelihood options, and institution capacity - are the axes of a three-dimensional vulnerability framework influenced by climate change- the same natural driver as in our llamas case-and socioeconomic factorsour anthropogenic drivers and assets-that is fracturing large-scale pastoralist ecosystems into spatially isolated systems. This may be happening in our area, with Bolivian llameros staying in their territories and ceasing to travel to Argentinean fairs.

We have also suggested that another significant reason is that young local people have little personal interest in caravans as a component of their adult life (Vilá in prep). Since the llamero profession is learned as a teenager while travelling in a caravan with adults - usually parents and uncles-it is very important to understand the perceptions and attitudes of young people towards this activity. Teenagers that had travelled in caravans have stated that they were living in the city and studying (finishing secondary school), and that did not see caravanning as a suitable occupation for them. They did it for the experience and the sense of adventure, and to accompany their uncle, rather than as training for the future. Also, children at school stated that they did not enjoy walking for several days and sleeping outdoors, which was a very tiring and boring experience for them. They did not wish to be llameros when they grew up. 
Table 5 Main CF components in relation to llama nanobodies

\begin{tabular}{|c|c|c|c|c|}
\hline Components & Case study & Value & Description & other \\
\hline Nature & Llamas & $\begin{array}{l}\text { Intrinsic } \\
\quad \text { relational } \\
\text { instrumental }\end{array}$ & Domestic camelid & Can be used as lab animal \\
\hline $\begin{array}{l}\text { Nature contribution to } \\
\text { people }\end{array}$ & VHH nanobodies & Instrumental & $\begin{array}{l}\text { Smaller and simpler than } \\
\text { those found in humans }\end{array}$ & $\begin{array}{l}\text { VHH fit into smaller and more } \\
\text { recessed binding sites on the } \\
\text { viral surface }\end{array}$ \\
\hline \multirow[t]{2}{*}{ Anthropogenic assets } & $\begin{array}{l}\text { Development of llama bio } \\
\text { management }\end{array}$ & Instrumental & $\begin{array}{l}\text { Llamas live in a corral near } \\
\text { the laboratory }\end{array}$ & $\begin{array}{l}\text { Tamed and trained for special } \\
\text { handling (e.g. inoculation, } \\
\text { collection of blood samples) }\end{array}$ \\
\hline & $\begin{array}{l}\text { Laboratories developing } \\
\text { therapeutics with llama } \\
\text { VHH }\end{array}$ & Instrumental & $\begin{array}{l}\text { State-of-the-art techniques } \\
\text { used in molecular biology }\end{array}$ & \\
\hline $\begin{array}{l}\text { Institutions and Govern- } \\
\text { ance and other indirect } \\
\text { drivers }\end{array}$ & $\begin{array}{l}\text { International Research insti- } \\
\text { tutions } \\
\text { National Research Council } \\
\text { CONICET, other national } \\
\text { institutions (INTA, Mil- } \\
\text { stein, Leloir) }\end{array}$ & Instrumental & $\begin{array}{l}\text { Research to produce biomedi- } \\
\text { cal products }\end{array}$ & $\begin{array}{l}\text { Many products can be patented } \\
\text { Nagoya protocol }\end{array}$ \\
\hline Direct natural drivers & $\begin{array}{l}\text { Housing conditions, tempera- } \\
\text { ture, food }\end{array}$ & $\begin{array}{l}\text { Instrumental } \\
\text { Relational }\end{array}$ & $\begin{array}{l}\text { Llamas must be housed and } \\
\text { handled with care }\end{array}$ & $\begin{array}{l}\text { In summer, they need to be } \\
\text { shorn }\end{array}$ \\
\hline $\begin{array}{l}\text { Direct } \\
\text { anthropogenic driver }\end{array}$ & Research on llama blood & Instrumental & $\begin{array}{l}\text { Several laboratories around } \\
\text { the world }\end{array}$ & $\begin{array}{l}\text { Techniques for blood collection } \\
\text { must follow animal welfare } \\
\text { protocols }\end{array}$ \\
\hline Good quality of life & $\begin{array}{l}\text { Can provide the cure for a } \\
\text { wide range of diseases, } \\
\text { including neurodegenera- } \\
\text { tive ones }\end{array}$ & Instrumental & $\begin{array}{l}\text { Therapeutic approaches } \\
\text { based on the novel camelid } \\
\text { nanobodies }\end{array}$ & $\begin{array}{l}\text { Many people in the world can } \\
\text { receive effective treatments } \\
\text { based on the molecules of } \\
\text { an animal that they do not } \\
\text { know and live thousands } \\
\text { of kilometers away. Health } \\
\text { telecoupling }\end{array}$ \\
\hline
\end{tabular}

On the contrary, the prospect of cutting-edge molecular research of llama nanobodies attracts young scientists from around the world. Llama nanobodies are now in the frontlines of research seeking to improve Coronavirus diagnosis and treatments in several countries.

This raises interesting points to be considered for integration into institutional and governance indirect drivers of change. A strong case could be made that, as co-creators of llamas and stewards of camelids, Andean IPLCs are responsible, at least to some extent, for the existence of llama nanobodies, the 14th of the NCP reporting category (Díaz et al. 2018). In view of increasing international interest, and considering the Nagoya protocol, this could have significant implications for Andean IPLC's rights over the use of llama nanobodies. This is a complex indirect driver to be analyzed in detail in the future.

\section{Conclusions}

As the concept of "buen vivir" (good living) was born in Andean altiplano communities, it constitutes a suitable case to analyze the relationship between Andean people and their environment using the IPBES conceptual framework. South American camelids (SACs) provide vital contributions to people that have intrinsic, relational, and instrumental value. There is a wide range of types of contributions depending on the stakeholders and their cultural and social backgrounds. The IPBES conceptual framework is a useful paradigm to approach the study of Andean livelihoods associated with and based on the breed and use of camelids.

Acknowledgements We want to thank our VICAM colleagues, Jorge Baldo, Veronica Rojo, Gisela Marcoppido, Malena Pirola, and Hugo 
Yacobaccio. We are grateful to the Santa Catalina people without whom we would have no answers to our questions about the diverse values of vicuñas and llamas, and especially to the local school's headmistress Ely Funes and the children in this unique school. We also appreciate the support of the students and authorities of the National University of Jujuy. We thank Dr. Alejandro Schinder for checking the section of this paper that focuses on llama antibodies. We are also grateful for the insightful comments by the two anonymous reviewers. The field work was funded by the Midori Prize for Biodiversity (2014), Argentina's National Research Council (CONICET) and PUEINECOA CONICET UNJU Project ( $\left.{ }^{\circ} 22920170100027 C O\right)$.

\section{References}

Aagesen D (2000) Crisis and conservation at the end of the world: sheep ranching in Argentine Patagonia. Environ Conserv 27:208215. https://doi.org/10.1017/S0376892900000229

Acebes P, Wheeler J, Baldo J, Tuppia P, Lichtenstein G, Hoces D, Franklin WL (2018) Vicugna vicugna. IUCN Red List Threatened Species. https://doi.org/10.2305/IUCN.UK.2018-2.RLTS.T2295 6A145360542.en

Antún M, Baldi R (2020) Choosing what is left: the spatial structure of a wild herbivore population within a livestock-dominated landscape. PeerJ 8:e8945. https://doi.org/10.7717/peerj.8945

Arias Arevalo P, Martinez Lopez B, Gomez Baggethum E (2017) Exploring intrinsic, instrumental and relational values for sustainable management of social-ecological systems. Ecol Soc 22:43. https://doi.org/10.5751/ES-09812-220443

Arzamendia Y, Vilá B (2012) Effects of capture, shearing and release on the ecology and behavior of wild Vicuña. J Wildl Manage 76:54-64. https://doi.org/10.1002/jwmg.242

Arzamendia Y, Vilá B (2015) Vicugna habitat use and interactions with domestic ungulates in Jujuy, Northwest Argentina. Mammalia 79:267-278. https://doi.org/10.1515/mammalia-2013-0135

Arzamendia Y, Bonacic C, Vilá B (2010) Behavioral and physiological consequences of capture for shearing vicuñas in Argentina. Appl Anim Behav Sci 125:163-170. https://doi.org/10.1016/j.appla nim.2010.04.013

Arzamendia Y, Baldo J, Rojo V, Samec C, Vilá B (2014) Manejo de vicuñas silvestres en Santa Catalina, Jujuy: investigadores y pobladores en búsqueda de la sustentabilidad y el buen vivir. Cuadernos INAPL-Ser Esp 2: 8-23. https://ppct.caicyt.gov.ar/ index.php/cinapl-se/article/view/6044

Baied C, Wheeler J (1993) Evolution of high andean puna ecosystems: environment. Climate and culture change over the last 12000 years in the Central Andes. Mountain Res Dev 13:145-156

Batisse M (1986) Developing and focusing the biosphere reserve concept. Nat Resour 12:2-11

IPBES (2019) Global assessment report on biodiversity and ecosystem services of the Intergovernmental Science-Policy Platform on Biodiversity and Ecosystem Services. In: Brondizio ES, Settele J, Díaz S, Ngo HT (eds) IPBES Secretariat, Bonn, Germany.

Carmanchahi P, Schroeder N, Bolgeri MJ, Taraborelli P, Ovejero R, Gregorio P, Moreno P, Novaro A (2015) Live-shearing effects on population parameters and movements in sedentary and migratory populations of guanacos. Oryx 49:51-59. https://doi.org/10.1017/ S0030605314000027

CEESP- UICN (2003) Descentralización y participación local en la conservación y manejo ambiental. Rev Symposium. https://porta lces.org/content/view/27/51/lang,spanish/

Christie M, Martín-López B, Church A, Siwicka E, Szymonczyk P, Mena Sauterel J (2019) Understanding the diversity of values of "Nature's contributions to people": insights from the IPBES
Assessment of Europe and Central Asia. Sustain Sci 14:12671282. https://doi.org/10.1007/s11625-019-00716-

Cieza León P (1959) [1553]. The Incas. Von Hagen VW (ed) University of Oklahoma Press, Norman.

Clarkson PB, Briones L (2001) Geoglifos, senderos y etnoarqueologia de caravanas en el desierto chileno. Boletin Museo Chileno de Arte Precolombino 8:35-45

Convenio internacional para la conservación y manejo de la vicuña (1979). https://www.conveniovicuna.org/

Custred G (1979) Hunting technologies in Andean culture. J Soc Am 66:7-12

Díaz S, Demissew S, Carabias J, Joly C, Lonsdale M, Ash N, Larigauderie A, Adhikari JR, Arico S, Báldi A, Bartuska A, Baste IA, Bilgin A, Brondizio E, Chan KMA, Figueroa VE, Duraiappah A, Fischer M, Hill R, Koetz T, Leadley P, Lyver P, Mace GM, Martin-Lopez B, Okumura M, Pacheco D, Pascual U, Pérez ES, Reyers B, Roth E, Saito O, Scholes RJ, Sharma N, Tallis H, Thaman R, Watson R, Yahara T, Hamid ZA, Akosim C, Al-Hafedh Y, Allahverdiyev R, Amankwah E, Asah TS, Asfaw Z, Bartus G, Brooks AL, Caillaux J, Dalle G, Darnaedi D, Driver A, Erpul G, Escobar-Eyzaguirre P, Failler P, Fouda AMM, Fu B, Gundimeda H, Hashimoto S, Homer F, Lavorel S, Lichtenstein G, Mala WA, Mandivenyi W, Matczak P, Mbizvo C, Mehrdadi M, Metzger JP, Mikissa JB, Moller H, Mooney HA, Mumby P, Nagendra H, Nesshover C, Oteng-Yeboah AA, Pataki G, Roué M, Rubis J, Schultz M, Smith P, Sumaila R, Takeuchi K, Thomas S, Verma M, Yeo-Chang Y, Zlatanova D (2015) The IPBES Conceptual Framework-connecting nature and people. Curr Opin Env Sust 14:1-16. https://doi.org/10.1016/j.cosust.2014.11.002

Díaz S, Pascual U, Stenseke M, Martin-Lopez B, Watson RT, Molnár Z, Hill R, Chan KMA, Baste IA, Brauman KA, Polasky S, Church A, Lonsdale M, Larigauderie A, Leadley PW, Van Oudenhoven APE, Van der Plaat F, Schröter M, Lavorel S, Aumeeruddy-Thomas Y, Ukvareva EB, Davies K, Demissew S, Erpul G, Failler P, Guerra CA, Hewitt CL, Keune H, Lindley S, Shirayama Y (2018) Assessing nature's contributions to people. Science 359:270-272. https:// doi.org/10.1126/science.aap8826 ((PMID: 29348221))

Dong S, Wen L, Liu S, Zhang X, Lassoie JP, Yi S, Li X, Li J, Li Y (2011) Vulnerability of worldwide pastoralism to global changes and interdisciplinary strategies for sustainable pastoralism. Ecol Soc 16:10. https://doi.org/10.5751/ES-04093-160210

Faye B (2016) The Camel, new challenges for a sustainable development. Trop Anim Health Prod 48:689-692. https://doi. org/10.1007/s11250-016-0995-8

Flores Ochoa JA (1977) Pastores de Puna. Instituto de Estudios Peruanos, Lima

Franklin WL (2011) Family Camelidae (camels). In: Wilson DE, Mittermeier RA (eds) Handbook of the Mammals of the World, vol 2. Hoofed Mammals Lynx Edicions (associated with IUCN and Conservation International), Barcelona, pp 206-246

Gimpel J, Bonacic C (2006) Manejo sostenible de la vicuña bajo estándares de bienestar animal. In: Vilá B (ed) Investigación, conservación y manejo de vicuñas. Macs, Buenos Aires, pp 113-132

Gonzalez B, Acebes P (2016) Reevaluación del guanaco para la Lista Roja de la UICN: situación actual y recomendaciones a futuro. GECS News 6:15-21

Grebe ME (1984) Etnozoología andina: Concepciones e interacciones del hombre andino con la fauna altiplánica. Estudios Atacameños 7:335-347. https://doi.org/10.22199/S07181043.1984.0007.00032

Gusinde M (1982) [1931]). Los indios de Tierra del Fuego. De la vida y del mundo espiritual de un pueblo de cazadores. (Die feuerland indianer). Centro Argentino de Etnología Americana, CONICET., Buenos Aires.

Ives CD, Abson DJ, Von Wehrden H, Dorninger C, Klaniecki K, Fischer J (2018) Reconnecting with nature for sustainability. Sustain Sci 13:1389-1397. https://doi.org/10.1007/s11625-018-0542-9 
Kadwell M, Fernandez M, Stanley H, Baldi R, Wheeler J, Rosadio R, Bruford M (2001) Genetic analysis reveals the wild ancestors of the llama and the alpaca. P Roy Soc. https://doi.org/10.1098/ rspb.2001.1774

Kasterine A, Lichtenstein G (2018) Trade in Vicuna Fibre: Implications for Conservation and Rural Livelihoods. Technical Report. International Trade Centre. Geneva, Switzerland. Report number: SIVC-18.13.

Kueffer C, Underwood E, Hirsch Hadorn G, Holderegger R, Lehning M, Pohl C, Schirmer M, Schwarzenbach R, Stauffacher M, Wuelser G, Edwards P (2012) Enabling effective problem-oriented research for sustainable development. Ecol Soc 17(4):8. https:// doi.org/10.5751/ES-05045-170408

Lichteinstein G, Vilá BL (2003) Vicuna use by Andean communities: an overview. Mt Res Dev 23:198-202. https://doi. org/10.1659/0276-4741

Lichtenstein G (2010) Vicuña conservation and poverty alleviation? Andean communities and international fibre markets. Int J Commons 4:100-121. https://doi.org/10.18352/ijc.139

Lichtenstein G, Carmanchahi PD (2012) Guanaco management by pastoralists in the Southern Andes. Pastoralism 2:16. https://doi. org/10.1186/2041-7136-2-1

Maffey L, Vega CG, Miño S, Garaicoechea L, Parreño V (2016) AntiVP6 VHH: an experimental treatment for rotavirus a-associated disease. PLoS ONE 11(9):e0162351. https://doi.org/10.1371/ journal.pone.0162351

Marin JC, Romero K, Rivera R, Johnson WE, González BA (2017) Y-chromosome and mtDNA variation confirms independent domestications and directional hybridization in South American camelids. Anim Genet 48:591-595. https://doi.org/10.1111/ age. 12570

Martin-Lopez B, Leister I, Cruz PL, Palomo I, Gret-Regamey A, Harrison PA, Lavorel S, Locatelli B, Luque S, Walz A (2019) Nature's contribution to people in mountains: a review. PLoS ONE. https ://doi.org/10.1371/journal.pone.0217847

Miotti L (2012) El uso de los recursos faunísticos entre los cazadores recolectores de Patagonia: tendencias espacio-temporales de las estrategias durante el Holoceno. Archaeofauna 21: 137-160. https ://revistas.uam.es/archaeofauna/article/view/6393/6870

Murra JV (1965) Herd and herders in the Inca State. In: Leeds A, Vayda A (eds) Man, culture and animals. American Association for the Advancement of Science, Washington, pp 185-215

Nielsen A (2002) La complementariedad entre los pastores del altiplano de Lipez (Potosí, Bolivia). Mundo de antes 3:137-162

Pratt D, Macmillan D, Gordon IJ (2004) Local community attitudes to wildlife utilization in the changing economic and social context in Mongolia. Biodivers Conserv 13:591-613. https://doi. org/10.1023/B:BIOC.0000009492.56373.cc
Redford K, Berger J, Zack S (2013) Abundance as a conservation value. Oryx 47:157-158. https://doi.org/10.1017/S0030605313000331

Sahley CT, Sanchez J, Torres JA (2004) Neoliberalism meets PreColumbian tradition: campesino communities and vicuña management in Andean Peru. Cult Agric 26:60-68. https://doi. org/10.1525/cag.2004.26.1-2.60

Unciti-Broceta JD, Del Castillo T, Soriano M, Magez S, Garcia-Salcedo JA (2013) Novel therapy based on camelid nanobodies. Ther Deliv 4:1321-1336. https://doi.org/10.4155/tde.13.87

Vilá B (2012) Camélidos Sudamericanos. Eudeba, Buenos Aires

Vilá B (2014) Una aproximación a la etnozoología de los camélidos andinos. Etnoecológica 10:1-16

Vilá BL (2015) Camélidos en Santa Catalina (Jujuy, Argentina): Manejo de vicuñas y caravanas de llamas. Etnobiología 13:19-37

Vilá B (2018) In the brink of extinction: llama caravans arriving to the Santa Catalina fair, Jujuy. J Ethnobiol 38:372-389. https://doi. org/10.2993/0278-0771-38.3.372

Vilá B, Wawrzyk A, Arzamendia Y (2010) El manejo de vicuñas silvestres (Vicugna vicugna) en Jujuy (Argentina): un análisis de la experiencia del proyecto MACS, en Cieneguillas. Rev Lat Conserv $1: 38-52$

Wesolowski J, Alzogaray V, Reyelt J, Unger M, Juarez K, Urrutia M, Cauerh VA, Danquah W, Rissiek B, Scheuplein F, Schwarz N, Adriouch S, Boyer O, Seman M, Licea A, Serreze DV, Goldbaum FA, Haag F, Koch-Nolte F (2009) Single domain antibodies: promising experimental and therapeutic tools in infection and immunity. Med Microbiol Immunol 1988:157-174. https://doi. org/10.1007/s00430-009-0116-7

Wheeler J, Hoces D (1997) Community participation, sustainable use, and vicuña conservation in Peru. Mt Res Dev 17:283-287

Yacobaccio H (2001) Cazadores complejos y domesticación de camélidos. In: Mengoni Goñalons G, Olivera D, Yacobaccio H (eds) El uso de los camélidos a través del tiempo. GTZ y ICAZ, Ediciones Del Tridente, Buenos Aires, pp 261-282

Yacobaccio H (2009) The historical relationship between people and the Vicuña. In: Gordon IJ (ed) The Vicuña. Springer, Boston. https ://doi.org/10.1007/978-0-387-09476-2_2

Yacobaccio H, Vilá B (2016) A model for llama (Lama glama Linnaeus, 1758) domestication in the southern Andes. Anthropozoologica 51:5-13. https://doi.org/10.5252/az2016n1a1

Publisher's Note Springer Nature remains neutral with regard to jurisdictional claims in published maps and institutional affiliations. 